\title{
Correction to: Socio-demographic determinants of unmet need for family planning among married women in Pakistan
}

\author{
Muhammad Farhan Asif* and Zahid Pervaiz
}

\section{Correction to: BMC Public Health (2019) 19:1226 http://orcid.org/10.1186/s12889-019-7487-5}

It was highlighted that in the original article [1] the authors reported the descriptive statistics without excluding the missing values. As the data of FSE was available for 3773 respondents the sample size was actually restricted to 3770 (for which the data of all variables was available). Furthermore, in the variable of Mass Media Exposure responses of "Yes" had been erroneously labelled as "No" and vice versa in word file. This Correction article shows the correct files, Table 1, and the correct sections of the article.

\section{Data source}

The data used in our study is taken from PDHS 201213, conducted by the National Institute of Population Studies (2013). The population of the survey consists of married women aged 15-49. A sample size of 14,000 women was selected out of which 6944 women belonged to urban areas and 7056 women were resident of rural areas. A number of 13,558 women were successfully interviewed. However, data for 9788 respondents was reported in the survey with some missing observations. Thus comprehensive data of all variables used in our study was available for 3770 women out of which 2179 belonged to rural and 1591 belonged to urban areas.

The original article can be found online at https://doi.org/10.1186/s12889 019-7487-5.

* Correspondence: farhanmalik510@gmail.com

Department of Economics National College of Business Administration and Economics 40-E/1 Gulberg III, Lahore, Pakistan

\section{Results}

According to the data reported in PDHS 2102-13, the prevalence of UMNFP in the country was found to be $21 \%$ with $9.65 \%$ for spacing and $10.4 \%$ for limiting during the year 2012-13. Socioeconomic characteristics of the respondent women are presented in Table 1.

Table 1 show that most of the respondents (58.9\%) fall in the age-group of 20 years to 39 years. Similarly, the highest number of respondents (21.1\%) lies in the age group of $45-$ 49 and the lowest number of respondents (2.9\%) fall in the age group of $15-19.57 .8 \%$ of the respondent women reside in rural areas as compared with $42.2 \%$ of urban women. Only $30.1 \%$ of the women have secondary or above secondary education whereas $66.2 \%$ women have no education and $13.4 \%$ of total women have primary education. $49.7 \%$ of the women's husbands have secondary or above secondary education and $36.9 \%$ are uneducated. Similarly, 29.9\% of the respondents have 5 or more than 5 children, 14\% have 4 children, $15 \%$ have 3 children, $15.3 \%$ have 2 children and $13.4 \%$ have 1 child. $21.3 \%$ have exposure to mass media regarding family planning methods whereas only $78.7 \%$ of them have no such exposure. But $85.4 \%$ of the women have FSE. According to women's employment status, $21.2 \%$ of the women are employed whereas $78.8 \%$ are unemployed.

Published online: 25 January 2021

\footnotetext{
Reference

1. Asif, Pervaiz. Socio-demographic determinants of unmet need for family planning among married women in Pakistan. BMC Public Health. 2019;19: 1226. https://doi.org/10.1186/s12889-019-7487-5.
} 
Table 1 Socio-Economic Characteristics of Married Women

\begin{tabular}{|c|c|c|c|}
\hline \multicolumn{2}{|l|}{ Socio-Economic Characteristics } & \multirow{2}{*}{$\begin{array}{l}\text { Frequency } \\
110\end{array}$} & \multirow{2}{*}{$\begin{array}{l}\text { Percent }(\%) \\
2.9\end{array}$} \\
\hline Women's age & $15-19$ & & \\
\hline & $20-24$ & 456 & 12.1 \\
\hline & $25-29$ & 569 & 15.1 \\
\hline & $30-34$ & 608 & 16.1 \\
\hline & $35-39$ & 589 & 15.6 \\
\hline & $40-44$ & 642 & 17.0 \\
\hline & $45-49$ & 796 & 21.1 \\
\hline \multirow[t]{2}{*}{ Region of Residence } & Rural & 2179 & 57.8 \\
\hline & Urban & 1591 & 42.2 \\
\hline \multirow[t]{4}{*}{ Women's Education } & No Education & 2497 & 66.2 \\
\hline & Primary & 451 & 13.4 \\
\hline & Secondary & 527 & 17.7 \\
\hline & Higher & 295 & 12.4 \\
\hline \multirow[t]{6}{*}{ Number of Living children of Women } & 0 & 40 & 12.4 \\
\hline & 1 & 432 & 13.4 \\
\hline & 2 & 527 & 15.3 \\
\hline & 3 & 609 & 15.0 \\
\hline & 4 & 596 & 14.0 \\
\hline & 5 or More & 1566 & 29.9 \\
\hline \multirow[t]{5}{*}{ Wealth status of Women's Household } & Poorest & 827 & 21.9 \\
\hline & Poorer & 804 & 21.3 \\
\hline & Middle & 744 & 19.7 \\
\hline & Richer & 663 & 17.6 \\
\hline & Richest & 732 & 19.4 \\
\hline \multirow[t]{4}{*}{ Husband's Education } & No education & 1393 & 36.9 \\
\hline & Primary & 504 & 13.4 \\
\hline & Secondary & 1151 & 30.5 \\
\hline & Higher & 722 & 19.2 \\
\hline \multirow[t]{2}{*}{ Fear of side effect for Contraceptive use } & No Fear & 3219 & 85.4 \\
\hline & Fear & 551 & 14.6 \\
\hline \multirow[t]{2}{*}{ Women's Employment status } & Employed & 800 & 21.2 \\
\hline & Unemployed & 2970 & 78.8 \\
\hline \multirow[t]{2}{*}{ Exposure of Mass Media } & No & 2966 & 78.7 \\
\hline & Yes & 804 & 21.3 \\
\hline
\end{tabular}

